\title{
ANJAK PIUTANG (FACTORING) DALAM EKONOMI ISLAM
}

\author{
Naerul Edwin Kiky Aprianto \\ Program Pascasarjana Ekonomi Syariah IAIN Purwokerto \\ Email:naerul_edwin@yahoo.com
}

\begin{abstract}
Abstrak. Anjak Piutang (Factoring) Dalam Ekonomi Islam. Dalam dunia bisnis, pelaku bisnis dan perusahaan selalu ingin memperlancar barang produksinya, sehingga dapat meningkatkan keuntungan dan mempercepat perputaran modal yang pada gilirannya akan mendorong pertumbuhan ekonomi. Dengan semakin tingginya kebutuhan masyarakat terhadap barang-barang, maka menyebabkan banyak perusahaan menyediakan dana segar yang diperoleh dari lembaga anjak piutang (factoring). Lembaga pembiayaan anjak piutang diartikan sebagai badan usaha yang melakukan kegiatan pembiayaan dalam bentuk pembelian dan atau pengalihan serta pengurusan piutang jangka pendek. Oleh karena itu, tulisan ini akan mengkaji tentang konsep anjak piutang (factoring) dalam perspektif ekonomi Islam dengan menggunakan pendekatan teori hiwalah. Selain itu, tulisan ini juga akan menguraikan manfaat dalam perjanjian anjak piutang (factoring), serta perbedaan konsep anjak piutang secara syariah dan konvensional.
\end{abstract}

Kata Kunci: Anjak Piutang, Hiwalah, Ekonomi Islam.

Abstract. The Factoring in Islamic Economics Perspective. In the business world, for business people always want to expedite the production of goods, so as to increase profits and accelerate capital turnover, which in turn will promote economic growth. Increasing social demand for consumer goods, causing many companies engaged in capital goods either fresh or fund provider called factoring for the period based on periodic payments agreed by the customer. Financial institutions interpreted as a business entity conducting financing in the form of a purchase or transfer and short term receivables and management of an enterprise of domestically or overseas transaction. In this paper, will learn about the business model of factoring this in terms of the economic law of Islam by using hiwalah theory approach. In addition, this article will explain the different concept of factoring sharia and the conventional.

Keywords: Factoring, Hiwalah, Islamic Economics. 


\section{Pendahuluan}

Dalam dunia bisnis, pelaku bisnis maupun perusahaan selalu ingin memperlancar barang produksinya agar dapat meningkatkan keuntungan dan mempercepat perputaran modal yang pada gilirannya akan mendorong pertumbuhan ekonomi. Dengan semakin tingginya tingkat persaingan antar perusahaan saat ini, akan memaksa perusahaan untuk memberikan pelayanan yang maksimal kepada para pelanggannya, di mana salah satu caranya adalah dengan mempermudah syarat pembayaran produk. Sekarang ini, perusahaan mempunyai alternatif lain untuk memperoleh dana tunai yaitu dengan menjual/mengalihkan faktur-faktur piutang yang dimilikinya ke lembaga anjak piutang (factoring).

Factoring yang dikenal dewasa ini pertama kali tumbuh di Amerika tahun 1889. Di Indonesia, factoring dikenal pada akhir tahun 1988 sejak berlakunya Keputusan Presiden Nomor 61 Tahun 1988 tanggal 27 Desember 1988. ${ }^{1}$ Anjak piutang (factoring) menurut Keputusan Presiden Nomor 61 Tahun 1988 adalah pembiayaan dalam bentuk dan/atau pengalihan serta pengurusan piutang atau tagihan jangka pendek suatu perusahaan dari transaksi perdagangan dalam dan luar negeri.

Dengan adanya perusahaan pembiayaan yang memberikan jasa pengalihan piutang dengan konsep anjak piutang (factoring), maka akan memberikan kemudahan bagi perusahaan untuk menyelesaikan piutangnya dan agar terhindar dari risiko yang tidak diharapkan seperti wanprestasi (ingkar janji) dari pihak lain (debitur). Oleh karena itu, selain dipraktikkan di perusahaan pembiayaan konvensional, anjak piutang juga dipraktikkan di perusahaan pembiayaan yang menggunakan prinsip syariah. ${ }^{2}$ Berdasarkan hal tersebut, tulisan ini akan mengkaji tentang konsep anjak piutang (factoring) dalam perspektif ekonomi Islam dengan menggunakan pendekatan teori hiwalah. Selain itu, tulisan ini juga akan menguraikan manfaat dalam perjanjian anjak piutang (factoring), serta perbedaan konsep anjak piutang secara syariah dan konvensional.

\section{Definisi Anjak Piutang (Factoring)}

Anjak piutang (factoring) apabila dilihat secara leksikal (kosa kata) terdiri dari dua kata, yaitu anjak dan piutang. Dalam hal ini, anjak diartikan berpindah atau 
Naerul Edwin Kiky Aprianto: Anjak Piutang...

bergerak, sedangkan piutang artinya uang yang dipinjamkan (yang dapat ditagih dari seseorang), atau tagihan uang perusahaan kepada para pelanggan yang diharapkan akan dilunasi dalam waktu tertentu sejak tanggal keluarnya tagihan. Jadi, anjak piutang adalah berpindahnya piutang atau perjanjian yang mendasari perpindahan tagihan sejumlah piutang kepada pihak lain. ${ }^{3}$

Anjak piutang (factoring) merupakan suatu usaha pembiayaan dalam bentuk pembelian atau pengalihan serta pengurusan piutang atau tagihan jangka pendek suatu perusahaan dari transaksi perdagangan dalam atau luar negeri. ${ }^{4} \mathrm{Hal}$ ini senada dengan Peraturan Menteri Keuangan Nomor 84/PMK.021/2006 tentang Perusahaan Pembiayaan dan Keputusan Presiden Nomor 61 Tahun 1988 tentang Ketentuan dan Tata Cara Pelaksanaan Lembaga Pembiayaan.

Dalam Peraturan Menteri Keuangan Nomor 84/PMK.021/2006 tentang Perusahaan Pembiayaan Pasal 1 (e) dinyatakan bahwa anjak piutang (factoring) adalah kegiatan pembiayaan dalam bentuk pembelian piutang dagang jangka pendek suatu perusahaan berikut pengurusan atas piutang tersebut. Sedangkan berdasarkan Keputusan Presiden Nomor 61 Tahun 1988 tentang Ketentuan dan Tata Cara Pelaksanaan Lembaga Pembiayaan bahwa perusahaan anjak piutang adalah badan usaha yang melakukan kegiatan pembiayaan dalam bentuk pembelian dan/pengalihan serta pengurusan piutang atau tagihan jangka pendek suatu perusahaan dan transaksi perdagangan dalam atau luar negeri. ${ }^{5}$

Secara konvensional, anjak piutang (factoring) didefinisikan sebagai kontrak di mana perusahaan anjak piutang menyediakan jasa-jasa sekurang-kurangnya antara lain jasa pembiayaan, jasa pembukaan (maintenance of account), jasa penagihan piutang, jasa perlindungan terhadap risiko kredit dan untuk itu, klien berkewajiban kepada perusahaan anjak piutang secara terus-menerus menjual atau menjaminkan piutang yang berasal dari penjualan barang-barang atau pemberian jasa-jasa. ${ }^{6}$

Anjak piutang (factoring) secara syariah dapat merujuk pada Fatwa DSN Nomor 67/DSN-MUI/III/2008 yang menyatakan bahwa anjak piutang syariah adalah pengalihan penyelesaian piutang atau tagihan jangka pendek dari pihak yang berpiutang kepada pihak lain yang kemudian menagih piutang tersebut kepada pihak yang berhutang atau pihak yang ditunjuk oleh pihak yang berhutang sesuai prinsip syariah. ${ }^{7}$ Selain itu, anjak piutang (factoring) secara syariah juga terdapat 
Islamiconomic: Jurnal Ekonomi Islam

Vol.8 No.1 Januari - Juni 2017

pada Peraturan Badan Pengawas Pasar Modal dan Lembaga Keuangan Departemen Keuangan (Bapepam-LK) Nomor PER-03/BL/2007 tentang Kegiatan Perusahaan Pembiayaan Berdasarkan Prinsip Syariah Pasal 1 dan Pasal 8. Sebagaimana Pasal 1 Ayat 1, anjak piutang (factoring) secara syariah adalah kegiatan pengalihan piutang dagang jangka pendek suatu perusahaan berikut pengurusan atas piutang tersebut sesuai dengan prinsip syariah. Sedangkan dalam Pasal 8 Ayat 3, disebutkan bahwa anjak piutang merupakan pengalihan piutang yang dilakukan berdasarkan akad wakâlah bil ujrah, yaitu pelimpahan kuasa oleh satu pihak (al-muwakil) kepada pihak lain (al-wakil) dalam hal-hal yang boleh diwakilkan dengan pemberian keuntungan (ujrah). ${ }^{8}$

Dalam kegiatannya, perusahaan anjak piutang melakukan: (1) mengambil alih tagihan suatu perusahaan baik dengan cara dibeli atau dengan cara lainnya sesuai dengan kesepakatan; dan (2) mengelola usaha penjualan kredit (pembiayaan) suatu perusahaan. Adapun sumber keuntungan perusahaan anjak piutang adalah biaya yang dikenakan kepada kliennya, yang terdiri atas: (1) jasa penagihan (service charge) yang besarnya tergantung pada kesepakatan; dan (2) biaya administrasi (discount charge) yang besarnya juga tergantung pada kesepakatan. ${ }^{9}$

Berdasarkan hal tersebut, sangatlah jelas bahwa perusahaan anjak piutang merupakan perusahaan yang membantu dalam mengelola masalah hutang piutang, baik pengambil alihan atau pembelian piutang yang bertujuan memperlancar kegiatan perusahaan dan menghindari kredit (pembiayaan) macet agar perusahaan yang mempunyai masalah hutang piutang dapat melaksanakan kegiatan operasionalnya dengan baik dan lancar. Perusahaan anjak piutang tersebut juga akan mendapatkan insentif/bonus (fee) tertentu dari perusahaan yang mempunyai masalah utang piutang.

\section{Macam-Macam Anjak Piutang (Factoring)}

Transaksi anjak piutang berkembang sejalan dengan meningkatnya berbagai kebutuhan supplier. Dalam praktiknya, terdapat beberapa macam anjak piutang. Adapun macam-macam anjak piutang (factoring) dapat dibedakan dalam berbagai bentuk yang dapat dilihat dari beberapa segi, sebagai berikut: 
Naerul Edwin Kiky Aprianto: Anjak Piutang...

1. Segi pemberitahuan kepada pihak customer, anjak piutang (factoring) dapat dibagi dalam bentuk:

a. Disclosed factoring, yaitu customer diberitahu bahwa tagihan telah dialihkan kepada lembaga factoring dan pembayaran dilakukan langsung kepada lembaga factoring tersebut.

b. Undisclosed factoring, yaitu pihak customer tidak diberi tahu tentang telah dialihnya piutang sampai terjadi sesuatu yang dapat menimbulkan risiko terhadap lembaga factoring tersebut. 10

2. Segi keterlibatan klien, anjak piutang (factoring) dapat dibagi dalam bentuk:

a. Recourse factoring, yaitu pihak klien ikut serta memikul risiko yang mungkin timbul atas tagihan yang dialihkannya. Factoring dapat saja mengembalikan tagihan yang telah dijual itu kepada klien dan ini harus dituangkan dalam kontrak factoring. Dengan jenis recourse factoring ini, pihak factoring diberikan hak opsi untuk menjual kembali piutang tersebut kepada klien. ${ }^{11}$

b. Non recourse atau without recourse factoring, yakni jenis ini membebankan semua tagihan beserta risiko terhadap tagihan yang tidak terbayar kepada perusahaan factoring. Namun, perjanjian factoring dapat dicantumkan bahwa di luar keadaan macetnya tagihan tersebut dapat diperlakukan recourse yang bertujuan untuk menghindari tagihan yang tidak terbayar karena pihak klien ternyata mengirimkan barang-barang yang cacat atau rendah mutunya. ${ }^{12}$

3. Segi jumlah hutang yang dialihkan, anjak piutang (factoring) dapat dibedakan menjadi:

a. Facultative factoring, yaitu pihak factoring diberikan hak opsi untuk menentukan apakah piutang diterima dengan kontrak factoring atau tidak. Sebelum piutang itu dinyatakan diterima, klien bebas menjual piutangnya kepada pihak lain.

b. Whole turn over factoring, yaitu perjanjian factoring dilakukan atas seluruh turn over (total keseluruhan dana yang ditransaksikan) dari perusahaan klien atas piutang yang ada atau yang akan datang. Hal ini untuk menghindari klien menjual piutangnya kepada pihak lain. ${ }^{13}$

4. Berdasarkan wilayah, anjak piutang (factoring) dapat dibedakan menjadi: 
Islamiconomic: Jurnal Ekonomi Islam

Vol.8 No.1 Januari - Juni 2017

a. Domestic factoring, yaitu kegiatan transaksi anjak piutang dengan melibatkan perusahaan anjak piutang, klien, dan customer yang semuanya berdomisili di dalam negeri.

b. International factoring, yaitu kegiatan anjak piutang untuk transaksi ekspor impor barang yang melibatkan dua perusahaan factoring di masing-masing negara sebagai expor factor dan import factor. ${ }^{14}$

\section{Manfaat Anjak Piutang (Factoring)}

Keterlibatan berbagai pihak dalam kegiatan anjak piutang akan memberikan atau memperoleh keuntungan bagi masing-masing pihak yang terlibat, baik perusahaan anjak piutang, klien, maupun customer. $^{15}$ Secara umum anjak piutang memberikan manfaat, sebagai berikut:

1. Manfaat bagi klien, di mana manfaat yang dapat diterima klien terdiri dari:

a. Manfaat karena menerima jasa pembiayaan, antara lain:

1) Peningkatan penjualan, yakni dengan adanya jasa pembiayaan memungkinkan klien melakukan penjualan dengan cara kredit (pembiayaan). Penjualan dengan kredit ini sebenarnya sulit untuk dilakukan apabila klien mengalami kesulitan modal. Namun dengan adanya jasa anjak piutang, klien mampu menjual dengan cara kredit. Penjualan dengan cara kredit meningkatkan kemampuan dan daya tarik bagi pembeli dengan dana terbatas.

2) Kelancaran modal kerja, yakni jasa anjak piutang memungkinkan klien untuk mengkonversikan piutangnya yang belum jatuh tempo menjadi dana tunai dengan prosedur yang relatif mudah dan cepat. Tersedianya dana tunai yang lebih besar ini dapat dimanfaatkan oleh klien untuk mendanai kegiatan operasional klien seperti pembelian bahan baku, pembayaran gaji pegawai, dan lain-lain.

3) Pengurangan risiko tidak tertagihnya piutang, yakni pembayaran dengan cara without recourse memungkinkan adanya pengalihan sebagian risiko tidak tertagihnya piutang kepada lembaga factoring. Pengalihan risiko ini sangat menguntungkan bagi kelancaran dan kepastian usaha bagi pihak klien. ${ }^{16}$ 
Naerul Edwin Kiky Aprianto: Anjak Piutang...

b. Manfaat yang diterima karena jasa non pembiayaan, antara lain:

1) Memudahkan penagihan piutang, yaitu jasa penagihan piutang yang diberikan oleh lembaga factoring yang dalam ini klien tidak perlu secara langsung melakukan penagihan piutang pada customer sehingga waktu dan tenaga karyawan dapat dimanfaatkan untuk melakukan kegiatan lain yang lebih produktif.

2) Efisiensi usaha, yakni jasa administrasi penjualan memungkinkan klien untuk mengelola kegiatan penjualan secara lebih rapi dan efisien karena administrasinya dilakukan oleh pihak factoring yang sudah lebih berpengalaman.

3) Peningkatan kualitas piutang, yaitu jasa administrasi penjualan memungkinkan pemberian fasilitas kredit kepada pembeli secara lebih efektif, sehingga kemungkinan tertagihnya piutang menjadi lebih tinggi. ${ }^{17}$

2. Manfaat bagi factor (lembaga factoring), di mana manfaat utama yang diterima lembaga factoring adalah penerimaan dalam bentuk fee dari pihak klien. Dalam hal ini, fee tersebut terdiri dari:

a. Discount fee, yaitu fee ini dibayarkan oleh klien kepada factor karena factor memberikan jasa pembiayaan (uang muka) atas piutang yang diberikan oleh factor. Discount fee diperhitungkan sebesar persentase tertentu terhadap besarnya pembiayaan yang diberikan atas dasar risiko tertagihnya piutang, jangka waktu, dan rata-rata tingkat bunga perbankan.

b. Service fee, yaitu fee ini dibayarkan oleh klien kepada factor karena factor memberikan jasa non pembiayaan yang nilainya ditentukan sebesar persentase tertentu dari piutang atas dasar beban kerja yang akan dilakukan oleh factor. Semakin besar volume penjualan, maka fee ini juga semakin besar. Semakin sulit penagihan piutang, maka fee ini juga semakin besar. ${ }^{18}$

3. Manfaat bagi customer, antara lain:

a. Kesempatan untuk melakukan pembelian dengan kredit, di mana dengan kehadiran jasa pembiayaan anjak piutang memungkinkan klien untuk melakukan penjualan secara kredit.

b. Pelayanan penjualan yang lebih baik, di mana jasa administrasi penjualan memungkinkan klien melakukan penjualan dengan lebih cepat dan tepat. ${ }^{19}$ 
Islamiconomic: Jurnal Ekonomi Islam

Vol.8 No.1 Januari - Juni 2017

Secara umum dengan adanya jasa dari perusahaan anjak piutang, klien mendapat manfaat dari transaksi yang diberikan. Klien mendapat kas langsung dari penjualannya dalam bulan berjalan dan tidak perlu menunggu waktu sampai pembayaran dari customer. Dengan demikian, likuiditas perusahaan akan lebih terjamin dan modal kerja akan terus bergulir. Kas yang diperoleh dari perusahaan anjak piutang dapat dimanfaatkan untuk menurunkan biaya produksi. Biaya produksi dapat dipangkas dengan memanfatkan diskonto dari para pemasok karena melakukan pemberian tunai. Pemberian tunai pastinya mendapatkan diskon. Besarnya diskon dapat digunakan untuk mengkompensasi biaya bunga yang dibayarkan kepada pihak perusahaan anjak piutang. Klien juga dibantu dari sisi administrasi piutang. Klien tidak perlu lagi melakukan penagihan kepada customer, karena perusahaan anjak piutang yang akan melakukannya sekaligus memberikan posisi piutang kepada klien. Laporan ini juga akan berguna ketika customer mengajukan kembali permohanan pembelian secara angsuran.

\section{Anjak Piutang (Factoring) dalam Perspektif Ekonomi Islam}

Anjak piutang merupakan suatu teknik pendanaan jangka pendek dengan memanfaatkan piutang yang dimiliki suatu perusahaan. Perusahaan yang bersangkutan menjual/menyerahkan hak atas piutangnya kepada perusahaan anjak piutang (factor). Factor dapat berupa sebuah bank atau lembaga keuangan. Kemudian factor akan menyerahkan uang kepada perusahaan tersebut sebesar persentase tertentu dari jumlah nilai piutang.

Konsep anjak piutang (factoring) yang berdasarkan prinsip syariah sering dikatakan sama dengan istilah hiwalah, karena secara operasional mirip dengan pelaksanaan hiwalah di perbankan syariah. Hal ini dikemukakan oleh M. Syafi'i Antonio dalam bukunya Bank Syariah: Dari Teori ke Praktik. ${ }^{20}$ Selain itu, konsep factoring syariah sama dengan istilah hiwalah juga dikemukakan oleh Herry Sutanto dan Khaerul Umam dalam bukunya yang berjudul Manajemen Pemasaran Bank Syariah. $^{21}$ Oleh karena itu, perjanjian pengalihan piutang atau anjak piutang (factoring) dalam fikih muamalah disebut dengan istilah hiwalah/ hawalah. ${ }^{22}$

Hiwalah merupakan pemindahan hutang dari satu tanggungan kepada tanggungan yang lain dengan hutang yang sama. ${ }^{23}$ M. Syafi'i Antonio menjelaskan 102 
Naerul Edwin Kiky Aprianto: Anjak Piutang...

bahwa hiwalah adalah pengalihan utang dari orang yang berhutang kepada orang lain yang wajib menanggungnya. ${ }^{24}$ Sedangkan menurut Zulkifli, hiwalah adalah akad pemindahan piutang nasabah (muhil) kepada bank (muhal 'alaih) dari nasabah lain (muhal). Muhil meminta muhal 'alaih untuk membayarkan terlebih dulu piutang yang timbul dari jual beli. Pada saat piutang tersebut jatuh tempo, muhal akan membayar kepada muhal 'alaih. Kemudian, muhal 'alaih akan memperoleh imbalan jasa pemindahan. ${ }^{25}$ Untuk mengantisipasi risiko kerugian yang akan timbul, bank perlu melakukan survey atas kemampuan pihak yang berhutang dan kebenaran transaksi antara yang memindahkan piutang dengan yang berhutang. ${ }^{26}$

Hukum hiwalah adalah mubah sepanjang tidak merugikan semua pihak. Namun demikian, hiwalah dibolehkan pada hutang yang tidak berbentuk barang/ benda karena hiwalah adalah perpindahan hutang. Hal ini didasarkan pada firman Allah SWT dalam QS. al-Baqarah ayat 245:

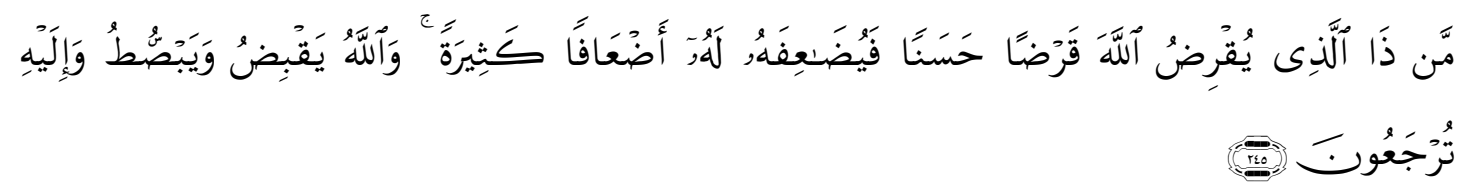

"Siapakah yang mau memberi pinjaman kepada Allah, pinjaman yang baik (menafkahkan hartanya di jalan Allah), maka Allah akan melipatgandakan pembayaran kepadanya dengan lipat ganda yang banyak. Dan Allah menyempitkan dan melapangkan (rezeki) dan kepada-Nya lah kamu dikembalikan." (QS. al-Baqarah [2]: 245)

Berdasarkan ayat di atas, Islam menganjurkan untuk melunasi hutang jika sudah sanggup membayarnya agar terlepas dari tanggung jawab. Jika sesorang mampu membayar hutang tetapi ia tidak melakukannya, maka ia bertindak zalim. Namun, jika tidak bisa membayarnya secara langsung, maka hutang tersebut dapat dialihkan kepada seseorang yang lain. Hal ini diperkuat dengan Hadis yang diriwayatkan Imam Bukhari dan Muslim dari Abu Hurairah bahwa Rasulullah SAW bersabda:

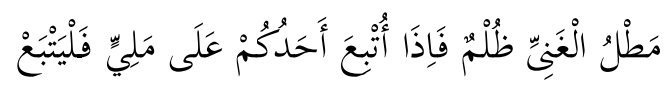

"Menunda pembayaran bagi orang yang mampu adalah suatu kedzaliman dan jika salah seorang dari kamu diikutkan (dihiwalahkan) kepada orang yang mampu/ kaya, terimalah hiwalah itu." (HR. Bukhari dan Muslim) 
Islamiconomic: Jurnal Ekonomi Islam

Vol.8 No.1 Januari - Juni 2017

Berdasarkan hadis tersebut, Rasulullah SAW memberitahukan kepada orang yang menghutangkan, jika orang yang berhutang meng-hiwalah-kan kepada orang yang mampu/kaya, hendaklah ia menerima hiwalah tersebut dan hendaklah ia menagih kepada orang yang di-hiwalah-kan agar haknya dapat terpenuhi. Dengan demikian, hiwalah ini sangat penting karena memudahkan penyelesaian hutang piutang, terutama dalam dunia perdagangan besar yang biasa menggunakan $c h e q u e^{27}$ dari bank. ${ }^{28}$

Dalam lembaga keuangan syariah, hiwalah merupakan akad pelengkap yang dimaksudkan untuk mempermudah pelaksanaan pembiayaan dan tidak ditujukan untuk mencari keuntungan, karena dasar akadnya adalah ta'awun atau tabarru'.29 Oleh sebab itu, tidak diperbolehkan adanya pengambilan keuntungan atas pelaksanaan akad tersebut. Hal ini dikarenakan inti dari akad tabarru' adalah untuk menolong/membantu orang yang mengalami kesulitan, misalnya kurang mampu dalam membayar hutang.

Saat ini setiap lembaga keuangan syariah mengenakan fee atas akad-akad tabarru' dengan alasan sebagai biaya administrasi. Sebagaimana hal ini dikemukakan oleh Siti Fatimah bahwa lembaga keuangan syariah saat ini mengenakan fee atas akad-akad tabarru' dengan alasan sebagai insentif atau bonus. ${ }^{30}$ Namun demikian, adanya anjak piutang bertujuan menghindari terjadinya kredit (pembiayan) macet dari pihak debitur yang akan mengakibatkan kerugian yang besar bagi pihak klien atau perusahaan klien, sehingga solusinya adalah pihak klien menjual piutang/ mengalihkan piutang kepada perusahaan factoring untuk memperlancar kegiatan penyelesaian hutang piutang dan membantu pihak klien dalam mengelola penjualannya secara kredit agar teratur yang timbul dari transaksi perdagangan. Secara umum, aplikasi hiwalah dalam lembaga keuangan syariah dapat digambarkan dalam diagram berikut ini: 


\section{Skema Hiwalah dalam Lembaga Keuangan Syariah}

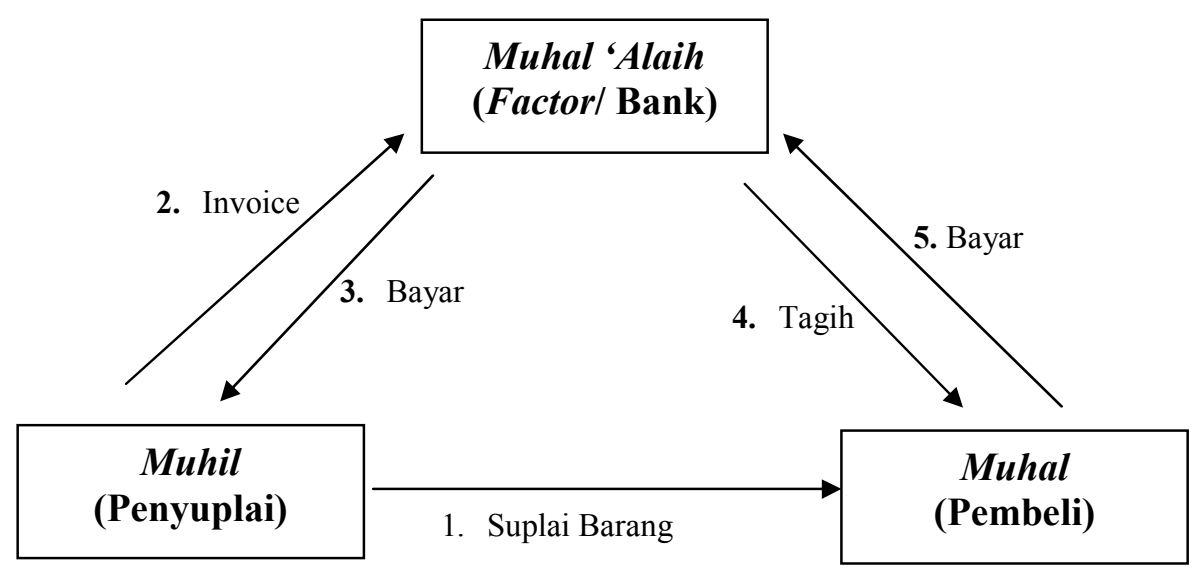

Sumber: M. Syafi'i Antonio (2001)

Berdasarkan skema di atas, dapat dijelaskan sebagai berikut: (1) Penyuplai (muhil) menjual barang kepada pembeli (muhal) secara pembiayaan (angsuran) dengan jangka waktu pendek; (2) Untuk kepentingan dana segar (cash flow), penyuplai (muhil) meminta persetujuan kepada pembeli (muhal) untuk menjual piutang tersebut kepada perusahaan lembaga pembiayaan (yang dalam hal ini perusahaan factoring) yang disebut dengan factor/ bank. Data mengenai piutang yang berasal dari jual beli tersebut, oleh penyuplai (muhil) diteruskan atau dipindahkan kepada factor/bank (muhal 'alaih). Atas dasar itu, maka dibuatlah perjanjian factoring antara penyuplai (muhil) dan factor/bank (muhal 'alaih); (3) Factor/bank (muhal 'alaih) membayar kepada penyuplai (muhil) atas hutangnya pembeli (muhal); (4) Factor/bank (muhal 'alaih) menagih kepada pembeli (muhal) terhadap barang tersebut; (5) Setelah jatuh tempo, maka pembeli (muhal) membayar hutangnya kepada factor/bank (muhal 'alaih).

Ketika merujuk pada Fatwa DSN Nomor 67/DSN-MUI/III/2008, akad yang digunakan dalam anjak piutang secara syariah adalah wakalah bil ujrah, di mana pihak yang berpiutang mewakilkan kepada pihak lain untuk melakukan pengurusan dokumen-dokumen penjualan kemudian menagih piutang kepada pihak yang berhutang atau pihak lain yang ditunjuk oleh pihak yang berhutang. Kemudian, pihak yang ditunjuk menjadi wakil dari yang berpiutang untuk melakukan penagihan (collection) kepada pihak yang berhutang atau pihak lain yang ditunjuk oleh pihak yang berhutang untuk membayar. Pihak yang ditunjuk menjadi wakil dapat 
memberikan dana talangan (qardh) kepada pihak yang berpiutang sebesar nilai piutang. Atas jasanya untuk melakukan penagihan piutang tersebut, pihak yang ditunjuk menjadi wakil dapat memperoleh ujrah/ fee. Sedangkan besarnya ujrah harus disepakati pada saat akad dan dinyatakan dalam bentuk nominal, bukan dalam bentuk prosentase yang dihitung dari pokok piutang. ${ }^{31}$

Dengan demikian, dapat dipahami bahwa pada prinsipnya anjak piutang syariah akan memberikan manfaat pembayaran piutang lebih cepat dari jatuh tempo, menambah dana segar perusahaan, dapat membantu peningkatan keuntungan yang merupakan sarana peralihan risiko tagihan yang tidak bisa dicairkan, serta akan memberikan kesempatan kerja bagi perusahaan factor untuk mendapatkan upah berupa ujrah.

\section{Perbedaan Anjak Piutang (Factoring) Syariah dengan Konvensional}

Konsep anjak piutang menurut Fatwa DSN-MUI merupakan konsep anjak piutang yang berdasarkan prinsip syariah, yang bertujuan untuk menghindari dari praktik yang dilarang oleh hukum Islam seperti riba, gharar, dan maisir. Hal ini juga memberikan kemudahan bagi para pelaku kegiatan anjak piutang untuk melaksanakan kegiatan anjak piutang berdasarkan prinsip-prinsip syariah, sebagaimana dalam kaidah fikih yang berbunyi:

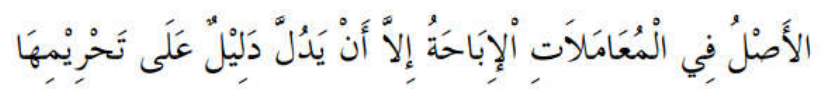

"Pada dasarnya, segala bentuk muamalat boleh dilakukan kecuali ada dalil yang mengharamkannya."

Berdasarkan kaidah di atas, menunjukan bahwa kegiatan anjak piutang diperbolehkan selama tidak bertentangan dengan prinsip syariah. Oleh karena itu, anjak piutang secara syariah yang diatur dalam Fatwa DSN-MUI Nomor 67 Tahun 2008 merupakan peraturan yang berdasarkan prinsip syariah dengan menggunakan akad wakâlah bil ujrah. Penggunaan akad wakâlah bil ujrah tersebut untuk membedakan anjak piutang syariah dengan anjak piutang konvensional. Secara umum, perbedaan anjak piutang syariah dengan anjak piutang konvensional, sebagai berikut: 
Naerul Edwin Kiky Aprianto: Anjak Piutang...

\begin{tabular}{|c|c|}
\hline ANJAK PIUTANG SYARIAH & ANJAK PIUTANG KONVENSIONAL \\
\hline $\begin{array}{l}\text { Sumber hukum yang dijadikan acuan } \\
\text { adalah aturan syariah yang } \\
\text { terkandung dalam al-Qur'an maupun } \\
\text { Hadis, serta Fatwa Dewan Syariah } \\
\text { Nasional (DSN) Nomor 67/DSN- } \\
\text { MUI/III/2008 tentang Anjak Piutang } \\
\text { Syariah. }\end{array}$ & $\begin{array}{l}\text { Sumber hukum yang dijadikan acuan } \\
\text { adalah Surat Keputusan Menteri Keuangan } \\
\text { tentang Anjak Piutang. }\end{array}$ \\
\hline $\begin{array}{l}\text { Pemberian balas jasa berupa ujrah/fee } \\
\text { dengan besar sesuai kesepakatan } \\
\text { bersama. }\end{array}$ & $\begin{array}{l}\text { Pemberian balas jasa berupa biaya yang } \\
\text { besarnya telah ditentukan oleh perusahaan } \\
\text { factor secara sepihak dengan acuan tingkat } \\
\text { diskonto/bunga. Nilai upah dihitung } \\
\text { berdasarkan presentase atas besarnya } \\
\text { piutang yang dialihkan. }\end{array}$ \\
\hline $\begin{array}{l}\text { Transaksi perdagangan harus terbebas } \\
\text { dari gharar, maysir, dan riba. }\end{array}$ & Bebas tidak ada ketentuan. \\
\hline $\begin{array}{l}\text { Objek penjualan antar supplier dengan } \\
\text { customer harus merupakan barang } \\
\text { yang halal. }\end{array}$ & Tidak ada batasan ketentuan objek. \\
\hline $\begin{array}{l}\text { Terdapat Dewan Pengawas Syariah } \\
\text { (DPS) yang mengontrol jalannya } \\
\text { aktivitas anjak piutang syariah sesuai } \\
\text { atau tidaknya dengan ketentuan Islam. }\end{array}$ & $\begin{array}{l}\text { Tidak ada pengawas, artinya tidak ada } \\
\text { pengontrolan dalam mengoperasikan jasa } \\
\text { anjak piutang. }\end{array}$ \\
\hline $\begin{array}{l}\text { Akad yang dilakukan sesuai dengan } \\
\text { prinsip syariah berupa hiwalah, } \\
\text { wakâlah bil ujrah, dan qard. }\end{array}$ & $\begin{array}{l}\text { Akad yang dilakukan berupa perjanjian } \\
\text { yang berpayung hukum negara tanpa } \\
\text { menyesuaikan prinsip syariah. }\end{array}$ \\
\hline $\begin{array}{l}\text { Dalam hal mengoperasikan anjak } \\
\text { piutang syariah harus mengutamakan } \\
\text { prinsip ta'awun (tolong-menolong), } \\
\text { kemudian profit/keuntungan. }\end{array}$ & $\begin{array}{l}\text { Lebih diutamakan adalah profit sebesar- } \\
\text { besarnya. }\end{array}$ \\
\hline $\begin{array}{l}\text { Menerapkan nilai-nilai keislaman } \\
\text { dalam menjalankan anjak piutang } \\
\text { syariah dengan prinsip kejujuran yang } \\
\text { akan menciptakan } \\
\text { kepercayaan. }\end{array}$ & $\begin{array}{l}\text { Tidak ada tuntutan hukum jelas yang } \\
\text { mengatur kejujuran dalam menjalankan } \\
\text { anjak piutang. }\end{array}$ \\
\hline
\end{tabular}

Berdasarkan perbedaan tersebut, setiap produk dan pelayanan jasa di perbankan syariah tidak terlepas dari Dewan Syariah Nasional Majelis Ulama 
Islamiconomic: Jurnal Ekonomi Islam

Vol.8 No.1 Januari - Juni 2017

Indonesia (DSN-MUI) yang mengeluarkan fatwa terkait produk dalam perbankan syariah, agar suatu produk yang dikeluarkannya berlandaskan prinsip syariah. Dikeluarkannya produk pelayanan jasa dengan akad hiwalah didasarkan pada pertimbangan bahwa terkadang seseorang tidak mampu untuk membayar hutang kepada orang lain secara tunai. Oleh karena itu, agar pihak yang memberi hutang tidak merasa dirugikan, maka pihak yang berhutang mengalihkan hutangnya kepada pihak lain atau kepada bank syariah.

\section{Kesimpulan}

Berdasarkan pembahasan di atas, dapat dipahami bahwa anjak piutang (factoring) secara syariah dapat merujuk pada Fatwa DSN Nomor 67/DSNMUI/III/2008 yang menyatakan bahwa anjak piutang adalah pengalihan penyelesaian piutang atau tagihan jangka pendek dari pihak yang berpiutang kepada pihak lain yang kemudian menagih piutang tersebut kepada pihak yang berhutang/pihak yang ditunjuk oleh pihak yang berhutang sesuai prinsip syariah.

Sebagai salah satu alternatif pendanaan usaha, anjak piutang belum sepopuler jenis pendanaan yang lain, padahal alternatif pendanaan ini cukup menjanjikan terutama pada saat terjadinya krisis ekonomi. Oleh karena itu, kegiatan anjak piutang merupakan salah satu sumber dana bagi perusahaan yang memang sedang membutuhkan uang dengan segera yang semua kegiatannya diatur sesuai dengan peraturan hukum yang berlaku agar tidak merugikan salah satu pihak.

\section{Pustaka Acuan}

Antonio, Muhammad Syafi'i. 2001. Bank Syariah: Dari Teori ke Praktik. Jakarta: Gema Insani Press.

Asyhadie, Zaeni. 2005. Hukum Bisnis: Prinsip dan Pelaksanaannya di Indonesia. Jakarta: RajaGrafindo Persada.

Burhanuddin. 2010. Aspek Hukum Lembaga Keuangan Syariah. Yogyakarta: Graha Ilmu.

2009. Hukum Kontrak Syariah. Yogyakarta: BPPE Yogyakarta.

Darmawi, Herman. 2006. Pasar Finansial dan Lembaga-Lembaga Finansial. Jakarta: Bumi Aksara. 
Naerul Edwin Kiky Aprianto: Anjak Piutang...

Fatimah, Siti. 2008. "Tinjauan Hukum Islam terhadap Praktik $h$ jiwa>lah di BMT Bina Ikhsanul Fikri (BIF) Gedongkuning Yogyakarta", Jurnal Hukum Islam, Vol. 1, No. 2.

Fuadi, Munir. 1995. Hukum Bisnis dalam Teori dan Praktik. Bandung: Citra Aditya Bakti.

Jaziri, 'Abd ar-Rahman al-. 1994. al-Fiqh 'ala al-Mazahib al-Arba'ah, terj. Moh. Zuhri, dkk. Semarang: Asy Syifa'.

Karim, Adiwarman A. 2004. Bank Islam: Analisis Fiqh dan Keuangan. Jakarta: RajaGrafindo Persada.

Kasmir. 2013. Bank dan Lembaga Keuangan Lain. Jakarta: Rajawali Press.

Martono. 2010. Bank dan Lembaga Keuangan Lain. Yogyakarta: Ekonisia.

Pandi, Frianto dkk. 2009. Lembaga Keuangan. Jakarta: Rineka Cipta.

Pantouw, Rinus. 2006. Hak Tagih Faktor Atas Piutang Dagang. Jakarta: Kencana Prenadamedia Group.

Rindjin, Ketut. 2000. Pengantar Perbankan dan Lembaga Keuangan Bukan Bank. Jakarta: Gramedia Pustaka Utama.

Sudarsono, Heri. 2005. Bank dan Lembaga Keuangan Syariah. Yogyakarta: Ekonisia.

Sutanto, Herry dan Umam, Khaerul. 2013. Manajemen Pemasaran Bank Syariah. Bandung: Pustaka Setia.

Zulkifli, Sunarto. 2003. Panduan Praktis Transaksi Perbankan Syariah. Jakarta: Zikrul Hakim

\section{Catatan Akhir:}

${ }^{1}$ Zaeni Asyhadie, Hukum Bisnis: Prinsip dan Pelaksanaannya di Indonesia (Jakarta: RajaGrafindo Persada, 2005), hlm. 108.

${ }^{2}$ Burhanuddin S., Aspek Hukum Lembaga Keuangan Syariah (Yogyakarta: Graha Ilmu, 2010), hlm. 198.

${ }^{3}$ Frianto Pandi, dkk., Lembaga Keuangan (Jakarta: Rineka Cipta, 2009), hlm. 101.

${ }^{4}$ Herman Darmawi, Pasar Finansial dan Lembaga-Lembaga Finansial (Jakarta: Bumi Aksara, 2006), hlm. 211.

${ }^{5}$ Pengertian anjak piutang (factoring) yang didasarkan pada Peraturan Menteri Keuangan Nomor 84/PMK.021/2006 tentang Perusahaan Pembiayaan dan Keputusan Presiden Nomor 61 Tahun 1988 tentang Ketentuan dan Tata Cara Pelaksanaan Lembaga Pembiayaan juga terdapat di dalam Rinus Pantouw, Hak Tagih Faktor Atas Piutang Dagang (Jakarta: Kencana Prenadamedia Group, 2006), hlm. 5.

${ }^{6}$ Dahlan Siamat, Manajemen Lembaga Keuangan (Solo: Intermedia, 1995), hlm. 209. 
Islamiconomic: Jurnal Ekonomi Islam

Vol.8 No.1 Januari - Juni 2017

${ }^{7}$ Definisi anjak piutang secara syariah lebih lanjut dapat dilihat pada Fatwa Dewan Syariah Nasional (DSN) Nomor 67/DSN-MUI/III/2008 tentang Anjak Piutang Syariah.

${ }^{8}$ Anjak piutang (factoring) secara syariah yang merujuk pada Peraturan Ketua Badan Pengawas Pasar Modal dan Lembaga Keuangan Departemen Keuangan (Bapepam-LK) Nomor PER-03/BL/2007 tentang Kegiatan Perusahaan Pembiayaan Berdasarkan Prinsip Syariah juga terdapat di dalam Burhanuddin S., Aspek Hukum Lembaga Keuangan Syariah, hlm. 193-194.

${ }^{9}$ Ketut Rindjin, Pengantar Perbankan dan Lembaga Keuangan Bukan Bank (Jakarta: Gramedia Pustaka Utama, 2000), hlm. 152.

${ }^{10}$ Zaeni Asyhadie, Hukum Bisnis, hlm. 114.

${ }^{11}$ Munir Fuadi, Hukum Bisnis dalam Teori dan Praktik (Bandung: Citra Aditya Bakti, 1995), hlm. 110.

${ }^{12}$ Kasmir, Bank dan Lembaga Keuangan Lain (Jakarta: Rajawali Press, 2013), hlm. 274.

${ }^{13}$ Zaeni Asyhadie, Hukum Bisnis, hlm. 115.

${ }^{14}$ Kasmir, Bank dan Lembaga Keuangan, hlm. 276.

${ }^{15}$ Frianto Pandi, dkk., Lembaga Keuangan, hlm. 102.

${ }^{16}$ Martono, Bank dan Lembaga Keuangan Lain (Yogyakarta: Ekonisia, 2010), hlm. 139.

${ }^{17}$ Martono, Bank dan Lembaga Keuangan, hlm. 140.

${ }^{18}$ Martono, Bank dan Lembaga Keuangan, hlm. 141.

${ }^{19}$ Martono, Bank dan Lembaga Keuangan, hlm. 142.

${ }^{20}$ Muhammad Syafi'i Antonio, Bank Syariah: Dari Teori ke Praktik (Jakarta: Gema Insani Press, 2001), hlm. 127

${ }^{21}$ Herry Sutanto dan Khaerul Umam, Manajemen Pemasaran Bank Syariah (Bandung: Pustaka Setia, 2013), hlm. 222.

${ }^{22}$ Burhanudin S., Hukum Kontrak Syariah (Yogyakarta: BPPE Yogyakarta, 2009), hlm. 75.

23 'Abd ar-Rahman al-Jaziri, al-Fiqh 'ala al-Mazahib al-Arba'ah, terj. Moh. Zuhri, dkk (Semarang: Asy Syifa', 1994), hlm. 353.

${ }^{24}$ Muhammad Syafi'i Antonio, Bank Syariah, hlm. 126.

${ }^{25}$ Sunarto Zulkifli, Panduan Praktis Transaksi Perbankan Syariah (Jakarta: Zikrul Hakim, 2003), hlm. 29-30.

${ }^{26}$ Adiwarman A. Karim, Bank Islam: Analisis Fiqh dan Keuangan (Jakarta: RajaGrafindo Persada, 2004), hlm. 95.

${ }^{27}$ Cheque (cek) merupakan surat perintah tanpa syarat dari nasabah kepada bank yang memelihara rekening giro nasabah tersebut yang digunakan untuk membayar sejumlah uang kepada pihak yang disebutkan di dalamnya atau kepada pemegang cek tersebut. Artinya, jika kita memiliki cek dan cek tersebut adalah asli, maka bank harus membayar siapa saja (ada nama seseorang atau badan hukum) yang membawa cek ke bank yang memelihara rekening nasabah untuk diuangkan sesuai dengan persyaratan yang telah ditetapkan, baik secara tunai maupun pemindahbukuan. Lihat Kasmir, Bank dan Lembaga Keuangan Lain, hlm. 87 .

${ }^{28}$ Sudarsono, Pokok-Pokok Hukum Islam (Jakarta: Rineka Cipta, 1992), hlm. 475.

${ }^{29}$ Heri Sudarsono, Bank dan Lembaga Keuangan Syariah (Yogyakarta: Ekonisia, 2005), hlm. 71.

${ }^{30}$ Siti Fatimah, "Tinjauan Hukum Islam terhadap Praktik $\left.h\right\}$ iwa $>l a h$ di BMT Bina Ikhsanul Fikri (BIF) Gedongkuning Yogyakarta”, Jurnal Hukum Islam, Vol. 1, No. 2, 2008, hlm. 75.

31 Lebih lanjut konsep anjak piutang syariah dapat dilihat dalam Fatwa Dewan Syariah Nasional (DSN) Nomor 67/DSN-MUI/III/2008 tentang Anjak Piutang Syariah. 